Kościoła. Warto może teraz pisząc lub mówiąc o ekologii wymieniać jako jej zwolenników i protektorów nie tylko św. Franciszka, ale i wcześniejszego o 800 lat św. Bazylego Wielkiego.

Wracając do recenzowanej publikacji trzeba podkreślić jej przejrzystą strukturę, jej jasny i logiczny tok rozumowania oraz staranną szatę graficzną, chociaż i tu nie obyło się bez drobnych usterek, zwłaszcza literówek, jak np. s. 27, wiersz 4 od góry: „sytntezę" = syntezę; s. 31, przypis 64: „A. Biese, Die Entwickelung” =Entwicklung, to samo s. 188; s. 47, przypis 54 i s. 192: „Narecki, Stownik terminów arystotetesowych" - chyba Arystotelesowych, itd.

Mimo powyższych usterek rozprawę p. dr Ewy Osek oceniam bardzo wysoko i uważam ją za pracę nawet pionierską nie tylko na tle ekologicznej literatury polskiej, ale i europejskiej. Autorka udowodniła w niej wszechstronnie i przekonywująco, że najwcześniejszych chrześcijańskich ekologów i admiratorów przyrody posiadamy nie dopiero od XII i XII wieku, ale już w okresie patrystycznym, a pierwszym z nich był św. Bazyli Wielki, biskup Cezarei Kapadockiej. Można mieć nadzieję, że praca ta zapoczątkowuje kolejne badania nad przyrodą u innych Ojców Kościoła, jej Autorce zaś sugeruję, by w przyszłości dokonała pierwszego polskiego przekładu Heksaemeronu św. Bazylego, bo aktualnie chyba nikt w Polsce nie zna lepiej od niej tego dzieła. Proponuję również opublikowanie gdzieś nowego dokonanego przez nią przekładu na język polski 14. Listu św. Bazylego, zawierającego jeden z najpiękniejszych wczesnochrześcijańskich opisów przyrody. Razem z omawianą pracą stanowić będzie cenny patrystyczny przyczynek do pisanej ciągle historii ekologii.

Ks. Stanisław Longosz - Lublin, KUL

\title{
SCRIPTURAE LUMEN: Biblia i jej oddzialywanie 1, red. bp A. Czaja - ks. A. Paciorek - ks. A. Tronina, Lublin 2009, Wydawnictwo KUL, ss. 751.
}

Pod koniec 2009 r. w Wydawnictwie KUL ukazała się publikacja, która formalnie jest pracą zbiorową, ale wyraźnie sygnalizuje ambicję stania się znaczącym periodykiem w obszarze teologii polskiej. Periodyk ten (z zapowiedzi wynika, że ukazywać się będzie jeden raz w roku) nosi ogólny tytuł „Scripturae Lumen”, w podtytule zaś czytamy: „Biblia i jej oddziaływanie”. Redakcję tomu stanowią bibliści i dogmatyk: ks. Antoni Paciorek - redaktor naczelny, ks. bp Andrzej Czaja oraz ks. Antoni Tronina; wszyscy trzej są znanymi i znaczącymi teologami w Polsce. Motorem przedsięwzięcia - jak zdaje się wynikać z tytułowych stronic - jest ks. prof. Antoni Paciorek, teolog-biblista, któremu m.in. zawdzięczamy pomyślnie rozwijającą się serię tzw. wielkich komentarzy do wszystkich ksiąg Starego i Nowego Testamentu: Nowy Komentarz Biblijny (NKB ST NT), a nadto dwie mniej znane serie: Podręczny Komentarz Biblijny (PKB NT ST - dopiero 3 tomy) oraz oryginalną albumową serię (także 3 tomiki), ukazującą życie Jezusa w perspektywie egzegetycznej i ikonograficznej. Wymienieni członko- 
wie Rady Naukowej periodyku - ks. Roman Bartnicki (UKSW), ks. abp Marian Gołębiewski (PWT Wrocław), ks. Sławomir Nowosad (KUL), ks. Waldemar Rakocy (KUL), ks. Marian Rusecki (KUL), o. Adam Sikora OFM (UAM), ks. Jan Walkusz (KUL), patronat zaś Komisji Nauki Wiary przy Konferencji Episkopatu Polski oraz nazwiska autorów artykułów wskazują, że mamy do czynienia z inicjatywą o zasięgu ogólnopolskim. Recenzentami naukowymi tomu byli: ks. prof. Jan Łach i o. prof. Celestyn Stanisław Napiórkowski OFMConv.

Z informacji zamieszczonych w nocie „Od Redakcji” dowiadujemy się, że zadaniem „Scripturae Lumen” będzie nie tylko poruszanie ważnych zagadnień biblijnych, ale także ukazywanie ich w perspektywie różnych dyscyplin teologicznych. Celem, jaki sobie stawiają redaktorzy, jest nie tylko prezentacja Biblii, ale prezentacja Biblii jako „duszy teologii”, a tym samym duszy chrześcijańskiego życia. Zdaniem redaktorów jest rzeczą bardzo ważną, aby w obliczu powszechnie doświadczanej specjalizacji dotykającej także teologię, próbować integrować różne dyscypliny teologiczne wokół Biblii, jako źródła Objawienia.

Tak zarysowanemu zamiarowi podporządkowano strukturę i tematykę serii. Każdy tom, podzielony na części, ma być poświęcony jednemu tematowi. Omawiany tutaj tom I poświęcony jest tematowi Królestwa Bożego i dlatego, w nawiązaniu do Mt 4, 23, został zatytułowany: „Ewangelia o Królestwie”. Podjęta tematyka - jak wynika z wstępnej dedykacji: „W dziewięćdziesiątą rocznicę powrotu Polski na mapę Europy" - nie jest przypadkowa. Jest to jedna z centralnych idei Biblii, idea Bożego królowania, która była w większym lub mniejszym stopniu natchnieniem i marzeniem pokoleń Polaków żyjących w mrocznych czasach rozbiorów.

Jak zrealizowano zamierzenie? W pierwszej części publikacji (SCRIPTURAE, s. 13-302) zostały zamieszczone artykuły (15) o charakterze ściśle biblijnym i egzegetycznym. Trudno byłoby nawet w wielkim skrócie przedstawić je tutaj, dlatego wymienimy jedynie tytuły oraz autorów: ks. J. Lemański - Królestwo Boże w Starym Testamencie; ks. S. Wypych - Wódz wojska Pana (Joz 5, 13-15)-poczqtki królowania Jahwe w Ziemi Obiecanej; ks. R. Rumianek - Proklamacja Królestwa Bożego wg Iz 25, 6-8; ks. M. Parchem -Władza Boga a imperia ziemskich królów: pojęcie Królestwa Bożego w Księdze Daniela; P.A. Kuśmirek - „Bóg wszelkiej mocy i potęgi, obrońca ludu izraelskiego" - królowanie Pana w Księdze Judyty; ks. T. Brzegowy - Królestwo Boże w Psalmach; ks. K. Bardski -Stworzenie kobiety (Rdz 2, 18-25) jako wczesnochrześcijańska alegoria narodzin Kościoła; ks. F. Mickiewicz - Orędzie Jana Chrzciciela o Królestwie Bożym (Mt 3, 2. 7-12; $Ł k$ 3, 7-9. 16-18) i jego wypetnienie się w działalności Jezusa; ks. Z. Żywica Tajemnice królestwa niebieskiego w przypowieściach Jezusa; według ewangelisty Mateusza (13); ks. R. Bartnicki - Przyszłość ,królestwa Bożego” w wypowiedziach Jezusa; ks. A. Paciorek - Darmowość Królestwa Bożego w logiach Jezusa; ks. M. Rosik - Rysy eschatologicznego Królestwa Bożego w Pawłowej nauce o zmartwychwstaniu (1Kor 15, 1-58); ks. M. Karczewski - Jezus Chrystus jako Król królów i Pan panów (Ap 17, 14b; 19, 16) na tle teologii Apokalipsy; ks. J. Flis 
- Królestwo Boże w świetle egzorcyzmów Jezusa; ks. W. Rakocy - Chrześcijanin mieszkańcem ziemi i obywatelem nieba. Jak widać, opracowania dotyczą problematyki Królestwa Bożego od najdawniejszych czasów Starego Testamentu aż po Ewangelie i Apokalipsę.

W części drugiej (LUMEN, s. 303-562) znajdziemy ideę Królestwa Bożego widzianą w perspektywie różnych dyscyplin teologicznych. Nie brak nawet artykułów z obszarów pozateologicznych, takich jak pedagogika, literatura, historia sztuki - malarstwo. W tej części znajdziemy następujące opracowania: ks. K. Góźdź - Królestwo Boże i królestwo Chrystusa; ks. K. Guzowski - Królestwo Boże a królowanie Chrystusa na ziemi; ks. M. Rusecki, Królestwo Boże w funkcji eklezjotwór czej w świetle Lumen Gentium; ks. J. Królikowski - Przepowiadanie Jezusa o Królestwie Bożym a natura i miejsce Kościoła w historii; ks. M. Wysocki Królestwo Boże w myśli pisarzy afrykańskich III w. na przykładzie Tertuliana i św. Cypriana; o. A. Derdziuk OFMCap - Problematyka Królestwa Bożego w teologii moralnej; ks. J. Popławski - Biblijne orędzie o Królestwie Bożym w duchowości polskich zmartwychwstańców; ks. M. Zając-Królestwo Boże w nauczaniu katechetycznym; ks. Teofil Siudy - „,Wywyższona przez Pana jako Królowa wszystkiego” (KK 59). Maryja Królowa w Królestwie Bożym; ks. J. Walkusz - Idea Chrystusa Króla i jego Królestwa w dziejach Kościoła. Zarys problematyki; ks. M. Nowak - Pedagogiczna lektura idei Królestwa Bożego i jej znaczenie dla nauczania $i$ wychowania; G. Kubski - Duch Święty - Król Wiekuisty”. O pewnej egzegetycznej osobliwości w traktacie „Ojcze nasz” Augusta Cieszkowskiego; A. Seul Królestwo Boże w Kazaniu na Górze wedlug Romana Brandstaettera; K. Klauza, Arcykapłan Królestwa. Hermeneje ikon tradycji bizantyjskiej; A. Kramiszewska - Idea Rex regum et Dominus dominantium jako czynnik ksztattujący ikonografie Jezusa w sztuce chrześcijańskiej Zachodu.

Część trzecia (s. 563-668) zawiera przekłady z obszaru szeroko rozumianej biblistyki. Sa to: Eposy ugaryckie o Kerecie i Akhacie. Wstęp, przekład i opracowanie - ks. Antoni Tronina; Benedykta Hessego komentarz do preskryptu Ewangelii św. Mateusza (Mt 1, 1). Wstęp, przekład, noty - ks. Antoni Paciorek; Historia przekładów Biblii na kaszubski w zarysie: Kazanie na Górze - o. A. Sikora.

W części czwartej, zgodnie ze schematem obowiązującym w czasopismach, znajdują się recenzje i omówienia publikacji o tematyce biblijnej (s. 669-693). Część piąta ma charakter sprawozdawczy i informuje o ważniejszych „wydarzeniach biblijnych", głównie w Polsce (s. 695-731). Całość zamykają obszerne wspomnienie o bibliście, ks. prof. Julianie Warzesze SAC, zmarłym 12 I 2009 r. (s. 733-736), a także noty o autorach (s. 739-745). Nietrudno zauważyć, że cała struktura „Scripturae Lumen” wzorowana jest na „periodyku „Vox Patrum”. Życzyć by sobie należało, by było w niej jak najwięcej artykułów z dziedziny egzegezy i biblijnej problematyki patrystycznej.

Nie sposób odnieść się do wszystkich kwestii zawartych w omawianym tomie. Ustosunkuję się do zasygnalizowanych w „Od Redakcji” głównych założeń pisma, następnie do ich realizacji, a później do jednej lub drugiej, bardziej szczegółowej 
kwestii. Otóż jest zasługą nie do przecenienia nie tylko samo dostrzeżenie aktualnego rozczłonkowania i atomizacji poszczególnych dyscyplin teologicznych, ale także próba integracji owych dyscyplin wokół Biblii, jako źródła Objawienia. Konkretnie dokonano tego poprzez spojrzenie na jedno i to samo zagadnienie z różnych punktów widzenia, z punktu widzenia biblisty, patrologa, dogmatyka, moralisty, pastoralisty i inych. Krótko mówiąc, problem został postawiony, potrzeba integracji ukazana, a nawet integracja ta w pewien sposób podjęta.

Propozycja jest czytelna. Badania teologiczne należy skoncentrować wokół Biblii jako źródła Objawienia. Staranność opracowania uderza w każdym szczególe (łącznie z punktacją samogłoskową w wyrazach hebrajskich oraz akcentami w zapisach słów greckich). Czy więc otrzymaliśmy zwarte, koherentne opracowanie teologiczne jednego $\mathrm{z}$ ważnych tematów? A może raczej otrzymaliśmy kolejny dowód atomizacji teologii i dowód na potrzebę jej integracji? Może jesteśmy dopiero w punkcie wyjścia? Otóż wydaje mi się, że patrząc nawet bardziej krytycznym okiem oraz oceniając bardziej surowym spojrzeniem przedstawioną inicjatywę, prawidłowa odpowiedź sytuuje się w pobliżu sugestii pierwszej. W pobliżu, bo oczywiście, praca zbiorowa nie będzie nigdy pracą jednego autora harmonijnie komponującego rozdziały, punkty i podpunkty. Praca tego typu zawsze wymagać będzie od czytelnika wypełnienia pewnych przestrzeni pomiędzy kolejnymi tematami prezentowanymi przez autorów. Sami zresztą redaktorzy zauważali ten problem, o czym zdaje się świadczyć zarys problematyki biblijnej o Królestwie Bożym poprzedzający część SCRIPTURAE (być może podobny zarys byłby potrzebny dla części LUMEN). Autor tego zarysu (ks. Antoni Paciorek) starał się ukazać biblijne orędzie o Królestwie Bożym w sposób jasny, przejrzysty i harmonijny, mając jak gdyby świadomość, że poszczególne artykuły dotyczyć będą zagadnień szczegółowych, a nawet bardzo specjalistycznych. Właśnie ze względu na ową specyfikę prac zbiorowych trudno byłoby spodziewać się, że nić tematyczna prowadzona będzie w sposób zupełnie harmonijny i jasny, nieomal na sposób wątku powieściowego. W pracy tego typu czytelnik sam będzie musiał po części tworzyć sobie zarys problematyki z jej „głównymi arteriami i zaułkami”. I tutaj zgoda. Niemniej jednak - jak mi się wydaje -pojawia się tutaj ważne pytanie, czy należy starać się o większą koherencję tematyczną tak pomyślanych opracowań i artykułów (co zapewne nie dokona się bez bliższych konsultacji autorów), czy raczej należy zostawić ową różnorodność, dzięki czemu czytelnik będzie mógł dostrzec odmienność i bogactwo podejść do danego tematu. Otóż wydaje mi się, że owo staranie o większą koherentność jest potrzebna. Być może jest to zadanie dla Redakcji, może także dla Rady Naukowej, ale tego rodzaju potrzeba - jak mi się wydaje - istnieje.

Pozostaje powiedzieć kilka słów na temat pozostałych części. Otóż bardzo interesująca i ważna jest część zatytułowana: „Przekłady”. Rozpoczyna je przekład autorstwa ks. A. Troniny dwóch eposów ugaryckich o Kerecie i Akhacie z epoki późnego brązu; przekład opatrzony jest wyczerpującym wstępem i komentarzem. Historycy zajmujący się starożytnym Bliskim Wschodem często 
odwołują się do tych eposów z Ugarit. Otrzymane przekłady litarackich pereł starożytnego Bliskiego Wschodu będą więc służyły nie tylko biblistom. Niemal ciekawostką biblijną jest przekład komentarza do Ewangelii Mateusza, a dokładnie do preskryptu tej ewangelii sporządzonego przez Benedykta Hessego, rektora i profesora Akademii Krakowskiej z czasów Władysława Jagiełły. Mamy sporo przekładów komentarzy ewangelii z czasów patrystycznych, istnieją także w przekładzie niektóre dzieła teologów średniowiecznych. $Z$ tym większym zatem zainteresowaniem należy powitać fragment monumentalnego dzieła polskiego teologa Benedykta Hessego. Dla polskiego egzegety jest on prawdziwie miłą niespodzianką: pozwala przyjrzeć się warsztatowi biblisty krakowskiego z XV wieku i posłuchać jego uniwersyteckiego wykładu na temat Ewangelii św. Mateusza. Problematykę przekładów na język kaszubski prezentuje o. A. Sikora. Autor jest nie tylko doskonałym znawcą przekładów na język kaszubski, ale jako rodowity Kaszub jest autorem przekładu Ewangelii z jeżyka greckiego na kaszubski. Fragment takiego przekładu (Kazanie na Górze) mamy okazję zobaczyć przy końcu opracowania.

Obok kilkunastu recenzji i omówień na uwagę zasługują także sprawozdania $\mathrm{z}$ „wydarzeń biblijnych”. Sens takich sprawozdań, to nie tylko informacja, ale zachęta do podejmowania podobnych działań. Taki właśnie sens zdaje się mieć informacja $z$ Wrocławia na temat duszpasterstwa biblijnego w Archidiecezji Wrocławskiej (ks. M. Rosik). Taki sens ma również informacja z Rzymu o jubileuszu (60 lat) Associazione Biblica Italiana (o. G. Witaszek) oraz pozostałe informacje z Jerozolimy, Lublina, Warszawy, Poznania i Katowic.

Last but not least. Bardzo trafny jest tytuł periodyku. Nie jest banalny, nie jest kalką obcojęzycznego tytułu. Wydaje się, że warto dołożyć wysiłku, aby znaleźć najbardziej odpowiedni i niepowtarzalny tytuł dla nowopowstającego periodyku. Tak właśnie stało się w przypadku „Scripturae Lumen”. Pismo otrzymuje swój niepowtarzalny charakter i nie jest powielaniem istniejących już na świecie tytułów. Czy inicjatywa wyrażona w tytule „Scripturae Lumen” zostanie podjęta? Czy zostanie udoskonalona? Jak mawiał mój dawny Katecheta posługując się cycerońskąłaciną, dabit se videre. Życzyć należy Twórcom „Scripturae Lumen” powodzenia i dalszych tak pięknych i merytorycznie znakomitych tomów.

Ks. Stanisław Longosz - Lublin, KUL 